$$
\begin{aligned}
& \text { SD } \\
& 11 \\
& A 47 \\
& 1910
\end{aligned}
$$

U.S. Cong. H.R. Committee on Expendditures in the Dept. of Agriculture. Forest Service. 


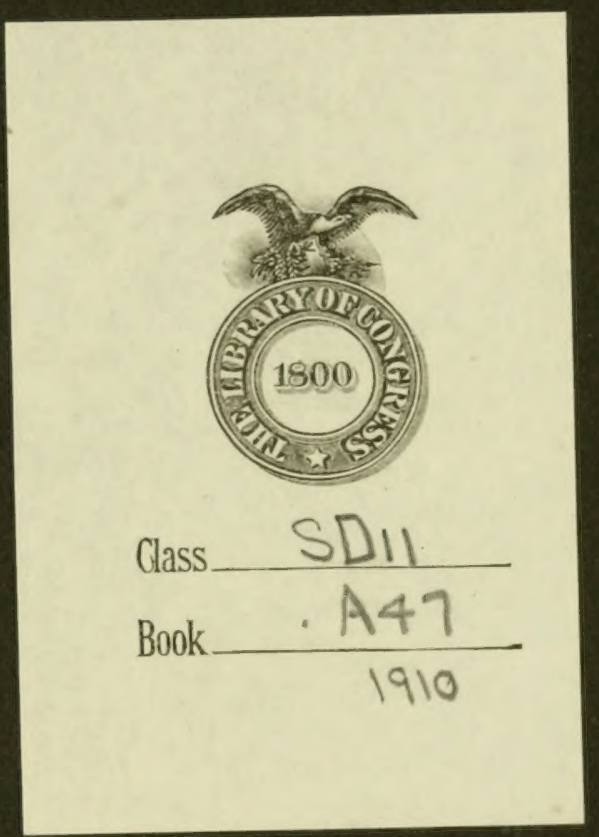




\section{FOREST SERVICE.}

\section{The Committee on Expenditures in the Department of Agriculture, Friday, June 10, 1910.}

The committee this day met, Hon. William H. Graham (chairman) presiding.

Present: Representatives Graham (chairman), Flood, Booher, and Moss.

STATEMENTS OF MR. HENRY S. GRAVES, FORESTER IN CHIEF; MR. ALBERT F. POTTER, ASSOCIATE FORESTER; AND MR. A. ZAPPONE, CHIEF DIVISION OF ACCOUNTS AND DISBURSEMENTS.

The Chatrman. Mr. Moss has some questions that he particularly desires to propound.

Mr. Moss. What is your station?

Mr. Potter. Associate Forester, Washington.

Mr. Moss. What are your official duties?

Mr. Potter. Assistant to the Forester, and in his absence from the office I am in charge of the Forest Service.

Mr. Moss. I am holding in my hand a Congressional Record of the date of March 11, 1910, and I am going to refer to some remarks made by Mr. Tawney, who is chairman of the Appropriations Committee, on that date and printed on page 3149 of the temporary Record. They will, of course, appear under date of March 11, 1910, in the permanent Record, but may not appear on that particular page. I will place this in the record. Mr. Tawney, speaking, said:

I find, to my amazement, that in one bureau, namely, the Forestry Bureau, during the fiscal year 1908 there were a great many employees in the Bureau of Forestry traveling-what for? To deliver addresses to women's clubs; addresses at county seats or educational questions, questions entirely foreign to forestry; addresses delivered at meetings arranged by Members of Congress in their own States, presumably in their own districts; and if I may have five minutes more I desire to read some of these items as tending to show the want of scrutiny with which the Committee on Agriculture has been investigating not orly these various expenditures in the Agricultural Department, but also the indifference of the committee as to the purposes for which the expenditures were made.

Would you regard that as being a criticism against your department?

Mr. Potter. Yes, sir; I would.

Mr. Moss. I thought so, and I felt, in justice to the department and more especially in justice to the members of this committee, that this matter should be taken up, and I will ask you some questions based upon Mr. Tawney's remarks, placing a copy of the remarks in the record later on. I would like to ask you to what extent have addresses been delivered at meetings arranged by Members of Con48961-10-1 
gress in their States and districts, those addresses being made by employees of the Forestry Bureau?

Mr. Potter. I have no knowledge of any such meetings.

Mr. Moss. Do you know whether or not that statement is true or false?

Mr. Potren. There has been no speaking by Forest Service men at meetings arranged especially by Congressmen for nearly two years. We have, upon the request of Congressmen, sent our men to address meetings of regular associations or regular meetings called in other ways, but not meetings arranged by the Congressmen themselves.

Mr. Moss. Then I call your attention to this particular statement, which you will find on page 3150 of the temporary Record:

Kellogg, R. S., Iuka, West Point, and Durant, Miss., Memphis, Tenn., and return, to deliver 13 addresses upon forestry at meetings arranged by Congressman Candler, of First Mississippi district.

Is that statement true or false?

Mr. Potrer. I could not say without looking it up to find out. Mr. Graves may have the papers with him.

Mr. Moss. Would your department recognize a request of that kind to arrange a series of 13 addresses by a Member of Congress?

Mr. Potter. It has done so in the past, but not recently. From the Forest Service point of view the question was one of educational opportunity. It was thought that the people would profit by getting together in meetings and having some one address them on forestry questions for the purpose of enlightening them as to forest preservation and the better utilization of forest products and giving them advice in reference to what they might do on their own wood lots in the way of forest improvement. There is a general interest along that line and we have a great many requests from associations and from meetings of the people to have our men come and talk with them and advise them as to the lines on which they should proceed to improve forest cônditions in particular localities.

Mr. Moss. What evidence of public interest would you require before you wotarrange a series of meetings like that?

Mr. Poттm. As a rule, requests from chambers of commerce, an association representative of interested people, gatherings of farmers, and other organizations of that kind which would be recognized as promising an audience which would profit by the information given.

Mr. Moss. I will refer a little more to the Record, and I wish to place in the record that in referring to this matter I have no personal interest in it, especially none as against the gentleman from Mississippi or the department, and I want you to place your construction upon this and have you meet it fully:

Mr. Tawney. The expense of delivering the 13 addresses in the first district of Mississippi, I might say, was $\$ 132.98$.

Mr. ManN. I know, but that is not important; but did it help to reelect the gentleman?

Mr. TAWNEY. I presume so. That was evidently the purpose. I could not imagine a more effective method of campaigning than that, especially if the Member can go around and introduce the gentleman from the department who has been brought there at his instance or through his influence and at government expense. No commendation to a Member's constituents is comparable to that which is apparently disinterested.

You will notice the statement: "That was evidently the purpose." Whose purpose, the purpose of the department or the purpose of Mr. Candler?

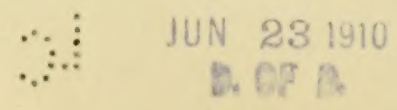


Mr. PotTer. It certainly was not the purpose of the department. The Forest Service felt assured that there was a public advantage in having Mr. Kellogg attend those meetings and talk on forestry questions. I would like to say that prior to Mr. Pinchot's separation from the service I was in charge of the Branch of Grazing, handling all the range questions, and had no connection with this part of the work.

₹ For that reason I am not personally familiar with the details of the trips.

Mr. Moss. If you will give us the name of the gentleman who can answer these questions, we will be glad to have him come before the committee.

Mr. PotTer. I can in a general way, except in detail.

Mr. Moss. I regard the statement in the Record as being unjust to $\mathrm{Mr}$. Candler. I want to say that it is either very unjust to $\mathrm{Mr}$. Candler or it is very unjust to the department, and that is a statement which has been made by one of the most prominent Members of the Congress upon the majority side, and the charge is that $\mathrm{Mr}$. Candler arranged these meetings to assist in his reelection.

Mr. Potwen. I think, Mr. Moss, that the records of the office will show that there was a decided response from the people there to the lectures, and that Mr. Candler requested the department to have some one go there because he knew the people would profit by the lectures.

Mr. Moss. Is Mr. Candler the only Member of Congress who has made a request of the department?

Mr. Potrer. No, sir. Except for one series of addresses in Alabama in the summer of 1908 there have been no addresses at meeting arranged by Congressmen, but we have, at the request of Congressmen, sent men to attend other meetings. I can not mention the exact cases, but under those conditions, that there was to be a general meeting. I can cite you one instance. The Kansas State Fair is going to be held this fall in Kansas and we have had a request from one of the Members of Congress to have one of our men deliver a few lectures there. The people are very much interested in tree planting in that section. They are going to have lectures on other subjects, and we have promised, at the request of a Congressman, to have one of our members deliver some lectures there. Those are the conditions under which we send men at the request of Congressmen.

Mr. Zappone. I would like to say that I can find no record of those expenditures in the travel report for the fiscal year 1909. If made, they must have been made in some prior year, 1908, or prior thereto. I ask permission to insert in the record the facts in this case.

Mr. Moss. I should be glad to have the matter placed in the record, if the chairman is willing.

Mr. ZAPPONE. There is nothing in the 1909 report at all. Therefore I need add nothing further to the record.

Mr. Moss. I would like to ask you again, so far as your knowledge goes, if there has been any relation between the Forestry Bureau and any Member of Congress that would justify the statement that men have been sent out at public expense to assist Members of Congress to secure their reelection?

Mr. Potter. No, sir; there is no justification for any such charge.

Mr. Zappone. Neither in the Forestry Bureau nor any other branch of the Department of Agriculture. 
The CHammax. It might be well to state that I have no recollection of any serious contest having been made against the reelection of any of the Mississippi Members in recent years. They seem to have matters all their own way. The very small vote shown in the districts would indicate no serious contest having been made against Mr. Candler or any other Mississippi Member in recent years.

Mr. Moss. Referring back to the statement: "To deliver addresses to women's clubs," on what occasions has the Forestry Bureau sent out lecturers to make addresses to women's clubs?

Mr. Potter. We had Mr. Hall, the assistant forester in charge of the Madison laboratory, attend the meeting of Federated Women's Clubs in Cincinnati, Ohio, a short time ago, upon their request to deliver a lecture to them on the subject of forestry. It happened that he was obliged to be in that neighborhood for other reasons just at that time, so that he could make the address practically without expense to the service, and for that reason the request for a speaker was granted. His lecture was principally on the importance of a full utilization of the forest products of the country, to prevent waste and so conserve our wood supply; and he explained to them the work which is being done in the Forest Service laboratories along the line of finding better uses for woods, in order that much of the timber which at the present time is being wasted may be utilized in manufacture, and that woods regarded as of inferior quality may be brought into use through preservative treatment or other improved methods. That is, to find a better utilization and more uses for inferior grades of timber that are not now used to any great extent, and to utilize more fully the waste from the mills. Forestry is a subject which the women's clubs of the country have alwajs taken a great interest in, and while we can not fill a great many requests of that kind, in the case of this recent large meeting of the Federated Women's Clubs in Cincinnati, we sent Mr. Hall to deliver a lecture and it was commented on in the newspapers as being one of the most interesting lectures delivered there.

Mr. Moss. Are the lectures delivered before these women's clubs especially prepared for women?

Mr. Potter. No, sir.

Mr. Moss. A different subject-matter than would be delivered before an association of men?

Mr. Potter. Not particularly.

Mr. Graves. May I interrupt there?

Mr. Moss. I should be glad to have you do se.

Mr. Graves. Before I entered the Forest Service I was connected with Yale University in the forestry department. I had occasion from time to time to give public lectures on invitation and occasionally, before women's clubs, among other audiences, and I always made it a point to talk on practical things. Just to give an illustration of the practical side of it, I will refer to one lecture which I gave in the State of Connecticut before a woman's club, in which I talked about the practical side of forestry, urging the people to introduce forestry in their woodlands, and as a result of that lecture before that club I got one of the large cities of Connecticut to start planting on its watershed, and I got one of the largest owners of woodlands in Connecticut to introduce forestry on his land. I simply speak of that as an illustration of the practical results of lectures, even before women's clubs. 
Mr. Moss. Is there anything in the subject-matter of these addresses delivered to women's clubs that ought to cause a Member of Congress to be filled with amazement?

Mr. PotTer. Not anything that I know of.

Mr. Moss. This is the statement that Mr. Tawney made:

I find, to my amazement, that in one bureau, namely, the Forestry Bureau, during the fiscal year 1908, there were a great many employees in the Bureau of Forestry traveling-what for? To deliver addresses to women's clubs.

The question is what kind of addresses is your department making that would fill a man with the experience of Mr. Tawney in public affairs with amazement?

Mr. PotTer. They are addresses on forestry along practical lines, to give them the information they are very anxious to have and to promote the best use of the forests of the country through the spread of knowledge concerning forestry.

Mr. Moss. "Addresses at county seats on educational questions, questions entirely foreign to forestry." What educational matters "entirely foreign to forestry" has your department been sending out lecturers to give?

Mr. Potter. None. I would like also for Mr. Graves to answer that question.

Mr. Graves. The address or lecture would refer to education in forestry.

Mr. Moss. Is that statement of Mr. Tawney's true or false?

Mir. Graves. I do not know what Mr. Tawney referred to. I do not know of any lectures on education except those pertaining to forest education. These concern instruction at forest schools, or the subject of introducing elementary forestry subjects into other schools, just as the subject of agricultural education is taken up in some of the schools. The end sought is to have the farmer's boy taught in school things that will enable him to handle the farm wood lot more intelligently.

Mr. Moss. As you were not present when I read this I will read it again for your information. It need not go into the record.

(Mr. Moss then read the statement referred to.)

Mr. Moss. Is that statement true or false?

Mr. Graves. No lectures have been given on education by members of the Forest Service that did not deal with instruction in forestry.

Mr. Moss. Are your sources of information such that if such lectures were given you would know it?

Mr. Graves. I have been in very close touch with the Forest Service for a number of years. In fact, I was connected with it ten vears ago. I know what the policy of the service in those matters has been. Of course, I have not seen the lectures, and did not attend the lectures, but I know what the policy has been, and I am confident that all lectures have been such as I have described.

Mr. Moss. So far as your information goes, you would consider that that criticism was not well founded?

Mr. Graves. I should, sir.

Mr. Moss. "Addresses at county seats on educational questions." That would indicate, I presume, that the addresses were located at county seats without regard to the question as to whether the people 
there were interested in that particular subject or not. I presume that would be a fair interpretation of the language. What governs the question of deciding where these lectures shall be given?

Mr. Potrer. It would simply be a question as to where the largest and most representative audience of the kind that could profit by the lecture could be assembled. Undoubtedly the people themselves had selected the county seat as the most convenient place to hold their meeting.

Mr. Moss. "In looking over this report," Mr. Tawney says, "I find that a man by the name of Betts went to New York to deliver an address before a Carriage Builders' National Association." Will you please tell the committee who Mr. Betts is?

Mr. Graves. Mr. Betts is connected with the branch of forest products, and as Mr. Potter has already explained in connection with the address of Mr. Hall before the Women's Federation we are very much interested in the question of wood utilization and the saving of waste. The purpose of that lecture undoubtedly-because it is like a good many lectures which have been given before industrial associations - was to interest those people in the subject of close utilization of forest products and the prevention of waste, and to assist them in learning of the various species which perhaps they do not know much about yet, and as to the strength of woods which they might use, but do not. For instance, the Forest Service tests have shown how present specifications as to hickory may be modified so as to reduce waste without reducing strength. It is a matter of public advantage that hickory users should know about this and also about the rate at which they are using up their supplies and where they will be a few years hence if they do not look ahead. In other words, to explain the uses of wood as applied to that particular industry, and the relation of forestry to future supplies. That undoubtedly was the reason for their requesting a lecture from him.

Mr. Mass. Is Mr. Betts regularly on the pay roll of the Government?

Mr. Graves. Yes, sir.

Mr. Moss. Where is his office?

Mr. Graves. Mr. Betts is now located at Denver.

Mr. Moss. His headquarters?

Mr. Graves. Yes, sir.

Mr. Moss. What is his salary?

Mr. Graves. Two thousand dollars.

Mr. Moss. What are his duties when at his office? Just give us a statement of his duties.

Mr. Graves. The headquarters of our product work is at Madison, Wis., where we have a laboratory and where the work on forest products is chiefly concentrated. In connection with the national forests there are a great many questions which come up in the utilization of woods in the West, and we have several men at our different headquarters in the West who have charge of that work. At Denver, in connection with district 2 , there is a great deal of demand for information and the gathering of information regarding forest products. For example, there is a good market for mine timbers, and the subject of preserving mine timbers so as to extend their life is a very important one to the mining industry. The question of wood preservation to enable the utilization of the lower grades of woods on the national forests for purposes for which there is now 
no market is also important. There are an enormous number of such local questions, and so we have at the district headquarters $\mathrm{Mr}$. Betts, who takes care of that work. Then we have in connection with the university at Boulder, Colo., a subsidiary laboratory where we are carrying on some experimental tests along these lines. Mr. Betts also has general direction of that work.

Mr. Moss. Coming back now to this specific statement that "Betts went to New York to deliver an address before a carriage builders' national association," what connection has the Bureau of Forestry with the Carriage Builders' National Association?

Mr. Graves. That is an association of wood users, their particular purpose being building carriages, and our relation to them is like our relation to many other industries and associated industries, to cooperate in every way we can in the matter of the use of woods, and to try to interest them practically in the adoption of measures which it is to the advantage of the public as well as to their own advantage that they should adopt. If we can give them information regarding the use of woods or the sources of woods, new species which they can use which will provide that industry in the future with the kind of woods they need, that has been considered one of our functions; that we should cooperate in that way because of the public need of forest conservation.

$\mathrm{Mr}$. Moss. Did an invitation come to the department for Mr. Betts to give this lecture, or did he volunteer his services?

Mr. Graves. Without question, there was an invitation.

Mr. Moss. From the association?

Mr. Graves. Yes, sir.

Mr. Moss. To Mr. Betts personally, or to the department?

Mr. Graves. To the department, I believe.

Mr. Moss. Then the department sent Mr. Betts?

Mr. Graves. Delegated Mr. Betts as the man who knew most about that subject.

Mr. Moss. Did this authorization come within the law?

Mr. Graves. I should think so; that has always been my judgment about it.

Mr. Moss. In your judgment, is it good policy?

Mr. Graves. Yes, sir.

Mr. Moss. And the expenditure of money was justified?

Mr. Graves. Yes, sir. This is an illustration: "H. S. Betts, address on structural timbers before the Connecticut Society of Civil Engineers, Washington to New York and return, expenditure, \$26.05."

Mr. Moss. The expense account is given as $\$ 12$ ?

Mr. Graves. This is the other item that Mr. Zappone spoke of. We have been carrying on experiments in the testing of the strength of different timbers, and this was an address on that subject showing the result of the work of the Forest Service.

Mr. Moss. Who is W. C. Barnes?

Mr. Potter. An inspector of grazing.

Mr. Moss. With headquarters at what point?

Mr. Potter. Washington.

Mr. Moss. What is his salary?

Mr. PotTer. Two thousand four hundred dollars.

Mr. Moss. When he is at his office he is here in Washington? 
Mr. Potrer. Yes, sir; but his work is largely in the inspection of grazing on the national forests in the West.

4. Mr. Moss. Tell us what his official duties are.

F Mr. PotTer. The inspection of the live-stock ranges on the national forests in the West. We have about 30,000 stockmen using the ranges in the national forests, who graze upon it about $7,800,000$ head of sheep and goats and 1,500,000 head of cattle. Mr. Barnes's principal duty is to inspect all that business in order that the Forest Service may conduct it in a businesslike way and in a way that will accomplish the objects which we have in the regulation of grazing, that is, the prevention of injury to the forests and at the same time the utilization of the forage resources of the land just as fully as possible.

Mr. Moss. The grazing is paid for?

Mr. Potter. Yes, sir.

Mr. Moss. Does Mr. Barnes have anything to do with collecting the rents?

Mr. Potter. No, sir. The charges for the permits are remitted direct to the United States depository by the permittee. When his application for a permit is approved a notice is sent him to remit a certain amount to the United States depository. Mr. Barnes has nothing whatever to do with the handling of the money.

Mr. Moss. What authority does Mr. Barnes have over flocks that he finds grazing on the public domain?

Mr. Potter. He would have authority to take any action necessary to protect the forest. If he found trespassing stock upon the national forest grazing without a permit, it would be within his authority to remove them, or if the circumstances appeared to warrant it, to arrest the man in charge of the stock and take him before a United States commissioner for hearing.

Mr. Moss. In his official capacity has he any business relation whatever with the men who own the stock grazing there?

Mr. Potter; Yes, sir; in talking over with them questions in regard to the range allotments, the proper seasons during which stock should be allowed to graze on a certain range, those are important matters in which he has direct authority. On his inspection trip if he finds a range is being used through too long a season, that the stock was allowed to go on too early, that is, before the range is ready, he would immediately take action to have that corrected. If he found that they were allowing 50,000 head of stock on a range which should have only 40,000 , he would immediately make a recommendation for the reduction of the number, so that the damage from over grazing might be checked. All of these things relate to a proper use of the forest.

Mr. Moss. In a measure the profits which would arise to the owners of the stock would come from his recommendation?

Mr. Potter. To some extent; yes, sir.

Mr. Moss. Mr. Tawney referred to a visit; I will read it:

To address members of Gunnison Stock Growers' Association, then to Denver to assist in adjusting grazing questions arising at American National Live Stock Association convention, and then to Salt Lake to attend supervisors' meetings and to attend to general grazing matters; expenses, $\$ 240.15$, paid from the general expenses, Forest Service, 1908.

Mr. Poтter. The meeting at Gunnison was a meeting of the stock men using the Gunnison national forest, upon which we are grazing 
something like 20,000 head of cattle, to talk over with them some range experiments which they wished to have conducted. They wore suflering loss from poisonous plants and they wele rery anxious to cooperate with the service by having an expert go there to examine and find out what poisomous plants were anusing the losis of the stock, and also to talk over with him questions of range allotment, dividing the range inte districts between diflerent (ommmmities and different associations of stock men, in order that ther might have a more satisfactory use of the range, and to talk over with them general matters pertaining to the use of the (xumnison national forest range. The address before the American lational Live Siteck Asseciation was upon the invitation of the association. That is one of the large live-stock associations of the country. The American National Live Stock Association and the National Wool Growers' Association are the two large stock associations which represent the stockmen of the country. A great many of the users of the national forestsare members of those associations, and at their conventions ther discuss methods for better utilization of the forest reserves, and it was in order that Mr. Barnes might be there to confer with them in regard to those matters that he attended the American National Live Stock meeting. Then at Salt Lake, he went there to meet the supervisors of the forests in that district. to talk with them in reference to grazing matters in their forests and to alvise them in reforence to future progress in that work.

Mr. Moss. The supervisor's' meeting-are the supervisors government officers?

Mr. Potter. Yes, sir.

Mr. Moss. What are their duties?

Mr. Potter. They are in direct charge of the mational forests. In District $t$ there are about 30 forests, each under the direct charge of a supervisor. He deals directly with the people on the forest.

Mr. Moss. Is Mr. Barnes a superior over the supervisors?

Mr. Potter. Yes, sir.

Mr. Moss. They are his subordinates?

Mr. Potter. Yes, sir.

Mr. Moss. It says: "To assist in adjusting grazing questions arising at American National Live Stock Association convention." What would be the questions which would arise at that convention?

Mr. Potter. Matters of general importance to the stock men as a whole which would come up at the convention, questions in reference to modifications of regulations would be discussed. At the supervisor's meeting there would be a discussion of the details of individual cases. There would he that difference. At the meeting of the association it would be a discussion of principles, and at the meeting of the supervisors a discussion of the details of individual cases.

Mr. Moss. I am quoting again from Mr. Tawney:

Mr. Barnes went to points in Illinois, Missouri, and return, to confer with officers of the General Federation of Women's Clubs for the courses of study of forestry

That relation would Mr. Barnes have with the general lederation of women's clubs on courses of study of forestry?

Mr. Potter. 'That was not Mr. Barnes, but Mr. Burns, who has charge of our publications, among other things. That trip) was made because the women's clubs were planning courses of study on the 
subject of forestry, to be pursued regularly by groups in diflerent clubs all over the country. Mr. Burns's trip was made also in order

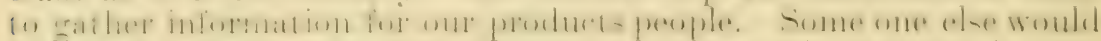
have had to be sent for this, if he had not been able to grather it, incidental to the other work.

Mr. Mloss. Was that an invitational trip)!

Mr. Potter. Yes, sir: I think so.

Mr. Moss. From whom was the invitation received?

Mr. Potren. From officinls of the fecteration.

Mr. Moss. In your judgment, does that work come within the seope of the work of your burean!

Mr. Potter. 'Yes, sir.

Mr. Moss. And the expenditure come within the terms of the appropriation law !

Mr. Potter. Yes, sir.

Mr. Moss. You would justify it as money well expended?

Mr. Potter. Yes, sir; I would. It is advising the people as to better means of utilizing the forest resources of the country.

Mr. Mloss. Mr. Burns went to New York City and returned to see about the preparation of piretures for enturational work in schools on the general subject of fore-try. What sehools were these pietures to be used in?

Mr. Potter. That I would have to look up. 'The records show that this trip was taken by Mr. Burns, the man in charge of the Forest Service publications. This travel was in 1908. At that time there Was a plan to geet out sets of pietures illustrating proper and improper ware of forests of diflerent kinds and regions in the Lnited states and forest products. The idea was that if half-tone sets of such pictures conld be made available for use in sehomk they eould be sent with accompansing printed matter which would enable them to be used

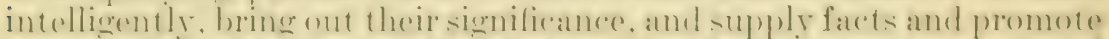
the teatehing of fore-try. Which in tum womld promete the practice of forestry. The plan had to be griven up beraume the cost of getting out the necessary number of pictures would have been too great. The demand for them from schools would probably have been heavy.

Mr. Mosis. Is the statement true that he mate the trip for that purpose?

Mr. Potrer. Lndoubtedly.

Mr. Graves. I do not know about that matter from my own knowledge, for it was two rears ago.

Mr. ZAPPOXE. All of the expenditures referred to by Mr. Tawney were made during the fiscal year 1908 or some prior fiscal year. 'They were not made in the fiscal year 1909, the year we have under discussion here.

Mr. Potter. I have not any personal knowledge of the trip, but undoubtedly Mr. Buren did make the trip for the purpose stated.

Mr. Moss. Will you tell the committee what interest the department is taking in preparing protures for educational work in schooks on the general subject of forestry?

Mr. Graves. There is very much interest along that line. We have a collection of photographs, and I know in the past that some-

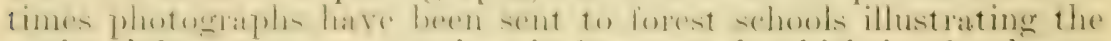
national forests or some points in forest work which is of value to the schools in training boys in forestry. We have a collection of 
photographs, and sometimes prints which have been rejected from the collection as better pictures become available are sent to schools which ask for pictures to use in connection with the teaching of forestry. Such pictures would be thrown away if they were not given away. But we have no regular arrangement for furnishing material to schools.

Mr. Moss. Is your department expending any money in getting up text-books or other work for forestry schools?

Mr. Graves. We have not gotten up any regular text-books, and of course we are not writing text-books as such. Some of our publications, however-as, for instance, Mr. Pinchot's Primer of Forestry-have been in wide demand for use in schools and school libraries. We have calls from schools, secondary schools, as to the sort of material that ought to be taught in the schools and what sort of work in forestry should be introduced in the rurat schools and agricultural high schools. We have sent out material of that sort to aid educators in solving that problem.

Mr. Moss. What class of schools, do you presume, would be included in this statement:

To see about the preparation of pictures for educational work in schools on the general subject of forestry.

Mr. Graves. I should say both forestry schools and others. This plan, howerer, dis not a through. Thether any pictures have been sent to other schools, except discards from the collection, I do not know. Do you, Mr. Potter?

Mr. Potter. No; I do not.

Mr. Graves. I do not know about that.

Mr. Moss. Judge Booher has suggested that the committee should have some of the pictures.

Mr. Graves. We have a very large collection of pictures and we would be glad to bring up some samples.

Mr. Booher. In that way the committee might get a better idea of their necessity and usefulness?

Mr. Graves. Yes, sir. We have about 22,000 pictures.

Mr. Moss. I think the committee would be interested in knowing to what extent your department is preparing pictures for use in forestry schools, and if rou are preparing pictures of that class, then the committee would like to see them.

Mr. Graves. We have a large collection of pictures and when a request is made we sometimes make loans where we think it will do good. I will be very glad to send some of the pictures to the committee.

Mr. Moss. Is R. S. Kellogg comnected with your department!

Mr. Potter. He was connected with the branch of products. IIe has left the service to accept a position with a private enterprice. During his employment he was connected with the branch of products and his work was largely in reference to the preparation of forest statistics.

Mr. Moss. Is he comnected with the department at the present time?

Mr. Potter. No, sir.

Mr. Moss. When did he sever his connection with the department?

Mr. Potter. About two months ago. 
Mr. Graves. Ite has some connection in this way: We call on him for assistance in the preparation of statistical work. We have no one now who can do it as well as Mrr. Kellogg can.

Mr. Moss. Did he discontinue his connection with the department because his officinl duties devolved upon some one else?

Mr. Grives. He retired because he wanted to become secretary of a lumber association in Wisconsin.

Mr. Moss. When he was with the department where was his office?

Mr. (imANES. In Washington.

Mr. Moss. I find in this report, quoting from Mr. Tawney:

Kellogg. IR. S., to Kaaterskill, I. Y., and return, to address semiamual meeting of Xational Aszociation of Box Manufacturers' Association.

What relation did Mr. Fellogg have with the Box Manufacturers' Association?

Mr. Graves. About the same relation as Mr. Betts hat with the Carriage Builders' Association. 'That is the same kind of a case. Unquestionably, an invitation came to the Forest Service for a lecture before that association, and Mr. Kellogr was selected to give the lecture.

Mr. Moss. Was the lecture given upon the invitation of the association?

Mr. Grares. Unquestionably.

Mr. Moss. Did that invitation come to the department or to Mr. Fielloger personally?

Mr. Graves. 'They come to the department, but sometimes an invitation of that kind will come to the department with a request for a certain man. I do not know whether that was so in that particular case.

Mr. Mloss. In rour judgment, does this work of Mr. Lelloger's come within the terms of your appropriation law?

Mr. Graves. In my judgment, it does.

Mr. Mloss. Do you feel that it is a good policy on the part of the department to comply with such requests?

Mr. Graves. I think within a limited measure, and where such lectures can reach woorl users or owners of woodlands and where the information will leat to a better utilization of forest or fores produrts. I feel, emphatically, it is justified.

Mr. Moss. These general expenditures have been referred to by Chatrman Tawner at an abuse erewing out of the fart that there hate

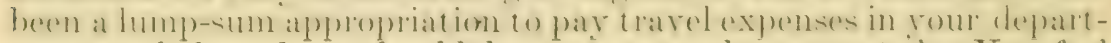
ment and that there should be some remedy suggested. You feel that it is not an abuse. Now, the fact that you are getting a lumpsum appropriation for travel. does that encourage semeling out and filling these invitations?

Mr. Graves. I do not know exactly how to answer that question, because I do not quite understand it, but there is an appropriation whieh in arailable for that purpeses which simply enables the semeliner out of the men. I should call an abuse sending out men where they

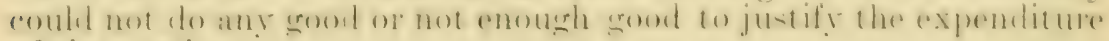
of time and money.

Mr. Moss. Let me read the exact language and then base a specific question upon it:

I do submit that there should be sufticient attention paid to these reports by the committees having jurisliction of appropriations for a specific department and the committee on expenditures in these departments, and to report to the House legisla- 
tion that will put a stop to the abuses that exist under general or lump-sum appropriations that are being expended in defraying the expense of departmental employees who are sent throughout the country promiscunsty for the purpore of delivering addreses upon any and upm every oreasion that they may be requested to do so, either by Members of C'ongress or by anybody else.

I will ask you some questions based upon that statement. First, under what conditions is rour department sending out members to make addresses? Tell us just exactly on what groumel reall would feel justified in sending out a lecturer.

Mr. Graves. Where the lecturer will reach an audience which needs information and can use information regarding the hetter utilization of forests or forest products, we do not send out men indiscriminately. There is an enormous number of requests which come in for lectures which we do not attempt to fill. We only send a lecturer out where we feel certain that he is going to reach an audience which needs the information. I should like to put in the following statement from the last annual report of the Forester concerning these addresses.

These were given, in response to requests, before gatherings of national forest users, tradle asorediations of wood users and similar bodies, chambers of commere and boards of trade, meetings of farmers, educational assemblies, and the like. Except as these addresses were made in the course of travel necessitated by other official duties, the expense incurred was usually reimbursed. Only a minor part of the requests for addresses could be granted.

Mr. Moss. Speaking of an audience, what constitutes an audience, in your mind?

Mr. Graves. I should say anywhere from 50 up. If they are the right sort of people, I think 50 men might just ify a lecture.

Mr. Moss. You have used the expression "right sort of people?"

Mr. Graves. I' mean men who need the information.

The Chamman. And who can utilize it?

Mr. Graves. Yes, sir. I have spoken before 50 farmers, each one an owner of woodland, telling how their woodland, in my judgment, could be better handled. I consider them the right sort of men, because they are owners of woodland and can utilize the information.

Mr. Moss. Is it your thought and does your department look forward to the time when you can send a lecturer to every 50 men who are interested in this work?

Mr. Graves. No, sir.

Mr. Moss. What proportion of those requests would you like to honor?

Mr. Graves. Only a very few.

Mr. Moss. How many would you like to honor?

Mr. Graves. From the standpoint of the Govermment, I do not see how we could possibly honor more than a few, associations like the Association of Civil Engineers of Comnecticut, or the carriage manufacturers, or some association of that sort, who are directly interested in the use of forest products.

Mr. Moss. You do not look forward to the time when you can honor all of them?

Mr. Graves. No, sir.

Mr. Moss. Only a very small percentage?

Mr. Graves. Yes, sir. 
Mr. Moss. Do you look forward to an increase in expenditures in sending these noris out!

Mr. (indres. No, sir.

Mr. Moss. To a decrease in expenditures!

Mr. Grares. Lunquestionably.

Mr. Moss. On what rround do you expect to decrease the expenditule's?

Mr. Cirnves. Because the need of the dissemination of information on forestry on the part of the Government and at the cost of the Govermment by methods of that sort is decreasing, because there is an incleasing knowledge, and because there is a constantly increasing number of other persons outside the Govermment who can meet the situation.

Mr. Moss. Is it not true, also, that there is an increasing demand for forestry work as our national forests become depleted?

Mr. Grives. Ies, sir.

Mr. Moss. But you still look to the fact that there will be fewer calls upon the Government in the future than in the past?

Mr. Graves. Fewer calls which can be justly accommodated.

Mr. Moss. Coming back to the question of the lump-sum appropriation, is there any abuse growing out of the expenditure of the lump-sum appropriation in your bureau?

Mr. Graves. I can not see how there is.

Mr. Moss. Has the fact that your department has been given a lump sum appropriation by Congress made you more liberal in using this appropriation than if we were to recommend that you be given rour appropriation on a diflerent basis?

Mr. Grates. I can not see why.

Irr. Zaproxe. In regard to the hmp fund appropriation for the Forest Service, I desire to sar, for the information of the committee, that Congress at its last session divided the appropriation into 150 heads or specific subappropriations, which action, I think, will cover absolutely evervthing that Mr. 'Tawner will desire in that direction. At that time it was the only bureau whose lump fund appropriation had not been so divided. The Forest Service was establishing outside districts and otherwise undergoing a reorganization, and consequently was not prepared to make that division when the appropriations of the other bureaus were subdivided, but promised to do so the next year. That has now been done to take effect from the 1st of July next.

The Cramux. You think that will answer the criticism?

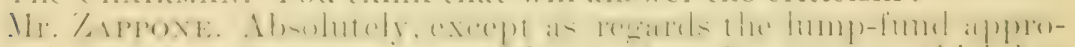

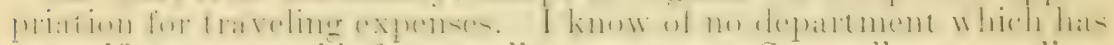
a specific sum set aside for tratreling expenses. Some allow a per diem

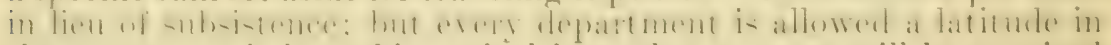
the matter, as it is problematical just what amount will be required for that purpose.

Mr. Moss. Mr. 'Tawney states further:

Every day they are absent from the department their regular work in the department ceases, and the Government is paying them their full salary and receives nothing in return.

When one of these men whose work is here in Washington leaves Washingtom and goes away, is it a fact that lis work here is neglected? 
Mr. Potter. No, sir; it is carried on by other members of the service.

Mr. Moss. You substitute a person in his place?

Mr. PotTer. Either that or some one who is carrying on another line of work who can look after the affairs of the office of the man who is away keeps his work going. We make a strong effort in the Forest Service to have the men in one line of work become thoroughly familiar with the details of the other lines of work, so that in an emergency of illness or a call for a man to go out for some special purpose there will be others there who are thoroughly competent to keep the work going, so there will be no check in the carrying on of the work.

Mr. Boomer. Will you tell me what connection the Forestry Service has with the New England Water Works Association?

Nrr. Graves. I think I can answer that, sir. Was that in connection with a lecture?

Mr. Booner. I see that Mr. Kellogg, on September 21-23, 1908, went from Washington to Atlantic City to address the annual meeting of the New England Water Works Association.

Mr. Graves. Well, as I am not familiar with that particular trip and do not know very much about that association, I assume, from my past experience with water companies in Xew England, that this was in connection with the practice of forestry on watersheds.

Mr. Boomer. Did this association invite Mr. Kelloggr to come there?

Mr. Graves. Unquestionably.

Mr. Booner. These water works associations are usually very wealthy and powerful, are they not, and abundantly able to pay their own expenses if they want lecturers?

Mr. Graves. The purpose of such a lecture would be to interest them in planting trees and taking care of the woods and the protection of the city watersheds.

Mr. Boomer. Would that be to their interest, to the advantage of the waterworks company, to do that?

Mr. Graves. It would involve, unquestionably, considerable additional expense in the management of the property, but it would be of value to the people in protecting the water.

Mr. Boorier. Would it be of value to the waterworks people, the men who own the waterworks?

Mr. Graves. I think so.

Mr. Booner. Well, why not let them pay the expense of it? Can you see any good reason why they should not?

Mr. Graves. Ordinarily I think they ought to do so, though it is improsible to make a haril-and-fast rute; at cood deat depends on the circumstances. They may not know enough about the subject to be fully awake to its practical value for them, and often the public value of getting them interested justifies the expenditure. I think they usually pay the transportation. I do not think there is anything charged up against the Government except for meals.

Mr. Boorer. Certainly, from the 21 st to the $23 \mathrm{~d}$, there would not be a charge of $\$ 15.25$ for meals alone. I see another item here to

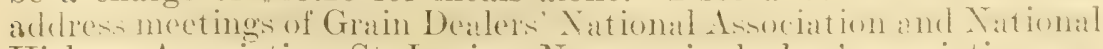
Hickory Association, St. Louis. Now, grain dealers' associations are usually composed of very wealthy people, as well as these hickory associations. Do you know anything about it? 
Ilr. Cimars. I know that we have been cooperating with hickory associntions with reference to the whole question of the supply of hickory timber and the sceuring of an adecunte supply of that timber, as it is beincre exhusted very fast.

Mr. Booner. Do you know who constitute this association? Is it not composed of such firms as the Studebakers and firms of that character, or that class of people?

IIr. Graves. I do not know, but undoubtedly they are people of rery substantial means.

Mir. Boonen. Now, the grain dealers' association, that is usually composed of grain speculators, is it not?

Mr. Graves. I do not know what that is; I could not answer your question about that.

Mr. Booner. Why should the Forestry Bureau pay out $\$ 67.60$ for an address by Mr. Kelloger at St. Louis and Chicago to members of

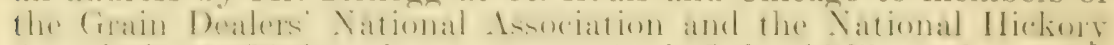
Association? If there is any reason for it $I$ should like to have you state it.

Mr. Graves. I know that we have been requiring recently that where addresses of that sort are given, wherever it is possible, to make the association pay the expenses.

Mr. Boomer. Do you not think it would be a good plan for the department to saly lo these associations, when they invite you to semel a lecturer, that you will do so if they will pay the expenses?

Mr. Potter. We have done that and are doing it now.

Mr. Booner. Do you not think that would be a good thing?

Mr. Potren. There might have been cases where that should have been done, sir.

Mr. Booner. Here is another that strikes me as being a little peculiar:

To discuss forest work with members of Kansas legislature and to attend annual meeting of Yellow P'ine Janufacturers' Association.

That was at 'Topeki, Kians.; New Orleans, La., January 12 to 23,

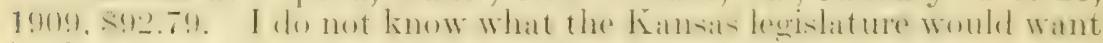
in that connection.

Mr. Graves. It was in connection with forest work and they wanted expert adrice.

Ir. Bones. Why did you not advise them that if they wanted that information ron world fumish it if they would paly the expenses? Do you not think the state of kiansas neght to hatre patid for that kind of work?

Mr. Graves. Possibly so. But undoubtedly at that time Mr. Pinchot thought the public good it would do would justify the expenditure.

Irr. Booner. I do not question the good faith of the department, but do you not think in cases of that kind the request ought to be refused unles the state of Katnsas and this lellow Pine Ilanufareturers' Association would pay the expenses?

Mr. Graves. We are doing that in a good many cases when we receive requests of that kind.

Mr. Booller. Of course, the yellow pine associations are very

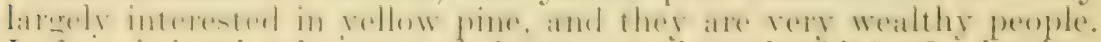
In fact, it is a lumber trust, is it not, or a branch of it? Ought they 
not to pay for the information they get from the Govermment? If they want a lecture on the subject their application ought to be rejected unless they put up the expenses.

Mr. Graves. The national association paid the expenses to New Orleans of an expert to talli on the subject of forest taxation this winter.

Possibly in some cases in the past expenses could have been collected where they were not collected. Yet the ability of the body before whom an address was made to pay the expenses does not, in my judgment, always mean that the expenses could or should have been collected. In the first place, most of the travel may really be on Forest Service business solely. Thus a man might be about to go west and receive instructions to stop on the way to make an address which had been asked for. This might, for example, change his first oflicial stop from Denver to ('incimati, and cause the first stage of his travel to be charged as made on account of the adchess. In the second place, the address may be made before a body which. is cooperating with the Forest Service, or whose cooperation is desired, in order that the Forest Service mar get information through its help; or it may be the desire of the Forest Service to secure a hearing in order to adrocate a course which it will be to the public: advantage to have adopted, if the persons addressed can be persuaded to do so.

Mr. Booner. This is a charge of $\$ 92.79$ in rour account - traveling expenses.

Mr. Graves. Well, we have often done exactly that thing, of requiring the payment of expenses.

Mr. Booher. I find another here from Washington to Seattle, Wash., January 29 to February 15, 1909, to address meetings of lumbermen at Sipoliane and Seattle.and give lectures at the Gniversity of Washington forest sehoul. Now, why should not the lumbermen's association at Spokane and Seattle pay their own bills? They are not poor people, are they?

Mr. Graves. I think that can be done in a great many cases.

Mr. Boofer. Do you not think that ought to have been rejectedthat is, their application-muless they womld pay the expenses? Do rou not think in the future it ought to be repuired by the department?

Mr. Graves. I think there are some cases where the Government ought to be represented at some large association mesting, and where it would be justifiable to pay the expenses; but where an association or a club can afford to pay and wants a lecture for its own profit, I agree with you that they ought to pay for it.

Mr. Booner. These lumbermen's associations are able to do anything they want to do, are they not?

Mr. Graves. In connection with the forestry schools we are adopting the same principle.

Mr. Boomer. I notice here a suggestion as to the giving of a lecture at the University of Washington forest school. Now, thint part of it I do not object to; I think that is right. I think that is a rery worthy expenditure of the money, but I do not see why the lumbermen of Spokane and Seattle ought not, if they want to have a lecture from the Govermment and particular information that is of benefit to them. to pay the expenses of the lecture. I hope the department in 
the future will see that they do, or else refuee their request. Now we go to the next item:

Washington to Philadelphia, l'a., and return, March 1, 1909, to address annual meeting of National Wholesale Lumber Dealers' Association.

There is another national lumber deaters association, men who are abumbanty ahle to pay these expenses il they want the information you genteimen have erathered, and they ought to be compelled to pay them. I think the department ought to lowk into these matters and correct what Mr. Tawney calls ahuse's. I do not go that far: I think it is an error in judgment in not compelling these people to pay these expenses. Here is one that is exactly right. 'This is money that ought to be expended, in my judgment:

Washington to $\mathrm{Ann}$ Arbor, Mich., and return, March 20 to 27,1909 , to give lectures to atudents of forestry at University of Michigan and State Agricultural College.

That is an expenditure which I think is justified, and which I think is right, berallse you are groing there among these students, the young men and women who are studring this branch in these colleges, and I think it is justifiable. But I 'an mot justify the expenditures for lectures to these assorciations that are ahundantly able to pay for them.

Mr. (instres. On a recent trip which I took West I went by way of New (Orleans - I had to go to the southwest anyway, I was going to Albuquerque and I went hy way of New (Orleans and there I attended a meeting of a lumber association: my leeture had the definite purpose of giving the mamner of starting forestry and forest protection on their lands, and I think we are going to geet a good deal of henefit from that lecture.

Mr. Bomens. There is no doubt about that ; but that was of direcet benefit to these peeple and they were abundantly able to pay vour expenses or part of your expenses on that trip, and they ought to have been required to do so, in my judgment.

Mr. Graves. Well, I made the lecture on my way to Albuquerque.

Mr. Booner. I know, but you conferred a great benefit on those people. you gave them information that the Government had been paring money to acpuire, and they erot the benefit of it : il they were not able to pay lor it it would be a different proposition. It is not like a school or a college that is kept up by the people enenerally. Here is a great assuebation of men who are very wealthy, and if they want information from rou peeple in the futcire rou ought to make them pay the expenses in order to get that information.

Mr. Graves. We have often required that.

Mr. Potren. We have started with that idea of requiring the association to pay the expenses of it, unless it was, in our opinion, a meeting which would be attended laredy by people outside of the members of the association and where it would do public good to give the information.

Mr. Bonere. of enurse, vou gentlemen have to use vour own juldement in these matters, bit I would sllgegest as a matter of economy alone that line, that these aseociations, if thes want the benefit of the knowledge the (iovernment lys gained, ought to pay your traveling expenses.

Mr. PotTen. I fully agree with you on that, if it is knowledge that they want for their individual profit. 
Mr. Moss. I am holdins in my hand a elipping from the investigation which was helel in lecirel to the Forestry service, erowing out of this investigation that Congress is making, and I am going to call attention to some items that are referred to, and referred to in this clipping, and which were referred to in the investigation: they were held by the counsel to be violations of the law and of good policy. And inasmuch as this is a part of the testimony and has become a matter of record, I felt it woukl be well to have the matter exwlained by the department directly responsible. I shall refer to matters that were given in testimony before this Pinchot-Ballinger investigation. Who is Mr. Bristow Adams?

Mr. Graves. Bristow Adams's title I do not remember; he is an expert, is he not? I think he is called an expert, and he has been assisting us in reviewing mamuscipts of pullications, and he has in the past-but I can not tell you to what extent--given occasional lectures, public lectures.

Mr. Moss. Where is his office when he is at his place of business?

Mr. Graves. Here in Washington.

Mr. Moss. What is his salary?

Mr. Graves. Seventeen hunilred dollars.

Mr. Moss. Is he in your employ at the present time?

Mr. Graves. Yes, sir; he is reviewing manuscripts now.

Mr. Moss. Mr. Bristow Adams made a trip to Chicago to meet members of women's clubs with regard to extension of forest edueation, and the cost to the Government was \$77.31. 'That was one item that was brought undej: criticism. What relation would Mr. Adams have to the members of the women's clubs with regard to the extension of forest education?

Mr. Graves. The extension of forest education there, without question, means the introduction or traching of forest subjects, and the teaching of trees and forestry. In the graded schools and the primary schools, even, ther are interesting the children in that subject now. That is a subject, of course, in which the women's clubs are very much interested, and that is the reason wliy he was there.

Mr. Moss. Was that trip made on an invitation coming from the women's clubs?

Mr. Graves. Undoubtedly. We do not make any voluntary trips, and never have as far as I. know.

Mr. Moss. I will say that these were referred to by Mr. Vertrees as giving evilence of the violation of law by the Departiment of Forestry. and that is the reason $I$ am referring to this. In your judgment, was the trip of Mr. Adams to Chicago within the scope of your law and activities of your department?

Mr. Graves. I suppose it was under the general heading of the idea of reporting or disseminating information with rosare? to forestry and the work of the Forest Service.

Mr. Moss. If that same invitation were to be repeated or to come from a like organization would it be accepted now?

Mr. Graves. We have been sending out no men at all since I have been in office to do any of that work, so far as I know.

Mr. Potter. Except to the meeting of the Federated Clubs at Cincinnati?

Mr. Graves. That was on the general subject of forestry, not on the subject of forest education. 
Mr. Bonner. Do you know of any time in the investicration where Mr. Vertrees male any objection to the amount of money that was

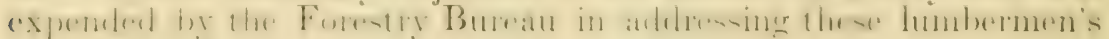
associations?

Mr. Moss. No.

Mr. Boonter. The only point he made was as to women's clubs which are engaged in teaching forestry.

Mr. Moss. I am bringing up these matters because they have been made a part of the record. Who is Mr. Fred Plummer, of your department :

Ifr. Graves. Mr. Plummer is an engineer who has been employed by the department for a good many years; he has been assisting in the exploration of the national forests, and has a very intimate knowledge of the forests of the West, and recently-I do not know

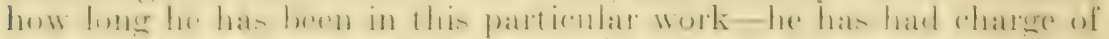
the compiling of maps of the national forests.

Mr. Moss. Where is his office?

Mr. Graves. His oflice is in Washington.

Mr. Moss. What is his salary?

Mr. Graves. 'Two thousand five hundred dollars.

Mr. Booner. Is that one of the things that Mr. Tertrees complained of too?

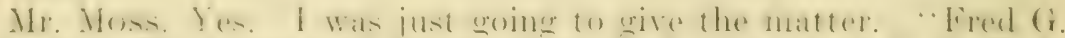

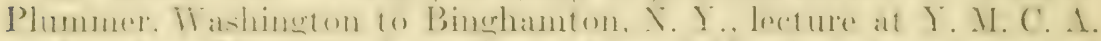

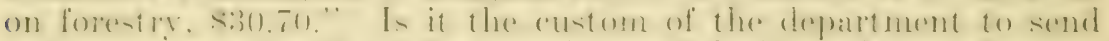
out lecturers to the Y. II. C. A. societies of the Uniterl States?

Mr. Graves. I do not believe that has been done: I do not know that we have had many requests, but I presume we have had some.

Mr. Howe. (an yon eqve any reatson why this partendar address was marle at the request of the Y. II. C. A. at that place?

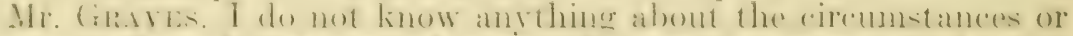
the invitation of that particular caise: I do not know enomeh about it to answer your question.

Mr. Moss. In general, would you think it was good poliey to send our lecturers to go to the Y. M. C. A.'s of the country?

Mr. GRores. I thould not think that was ordinarits an andience. that would justify a lecture, unless it was some exceptional place or

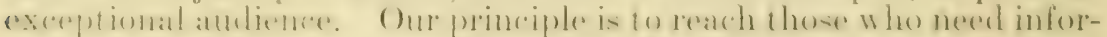
mation about the practice of forestry. I will put a statement about it into the record. The papers on file at the Forest Service show that this was not an ordinary meeting, but a state conference of 400 delegates and that the public was invited to attend the lecture.

Mr. Moss. The next item that I will call to your attentign, quoting

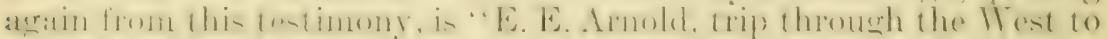
confer with local law oflicers and lecture on forestry at the University of Michigan, S5.31.\$4." In a general way what connection has your department with the local law oflicers of the comery?

Mr. Potter. Mr. Arnold is a member of our law force in the Forest Serrice and made a trip to the diflerent distriet oflices to confere with the local Forest Service law officers of the district oflices in reference to the greneral law business of the Forest Service. Incidental to that trip he delivered the lecture mentioned.

Mr. Mloss. 'These local law officers are public officials?

Mr. Potter. Ies, sir; law oflicers of the Forest Service; they are the legal antrisers of the district offices. 
The Cramsuas. Then that trip, in your judgment. would be clearly authorized by law ?

Mr. Potter. Yes, sir; it was largely administrative and the lecture was merely incidental.

Mr. Moss. I will say this, that I have assumed that these figures are correct, as I have not verified them. Who is Mr. Don Carlos Ellis?

Mr. Graves. He was appointed to the Forest Service as a clerkexaminer, as I recollect it; he is now transferred to the department to assist in reviewing manuscripts. He was helping us in our office of publication. Last summer he had charge of the exhibit of forestry at the exposition at Seattle, and gave lectures on forestry at the
Seattle exposition.

Mr. Moss. The item referred to is "Don Carlos Ellis, elucational talks at Seattle exposition, $\$ 152.85 . "$ Was he sent there for that purpose, to make those talks? Mr. Graves. He had charge of the exhibit at the exposition and
gave lectures.

The Chammis. You do not mean that he went to the exposition purposely to deliver the lectures?

Mr. Graves. He had charge of the whole exposition.

The Chamman. And these lectures were incidental?

Mr. Graves. Tes; they were incidental to the work there.

Mr. Moss. That was what I wanted to bring out, the question as to the circumstances under which those talls were given.

Mr. Potter. Mr. Ellis was in charge of the Forest service exhibit at Seattle.

Mr. Moss. Is it a fair statement to say that this expense account was for these educational talks at the Seattle exposition!

Mr. Potter. Not principally: no, sir; the expenses were principally on aceount of Mr. Ellis having to go there to he in charge of the exhibit of the Forest service in the govermment huilding at Seattle.

Mr. Moss. Who is Mr. William L. Hall?

Mr. Gruves. He is in charge of the branch of forest products, which now has its headquarters in Madison, Wis., in the new laboratory
there.

Mr. Moss. The item referred to and rriticised was. "William L. Hall, lecture on forest products at Yale Forestry School. \$26.25."

Mr. Graves. I was at that time in charge of the Yale Forest School, so I think I can answer that question. It was similar to the lectures which have already been referred to as being given at the Ann Arbor University and other sehools where members of the Furest Service have occasionally gone to give lectures. And he gave two or three lectures on the subject of forest products. sity?

Mr. Graves. Yes, sir.

Mr. Moss. And before the students of the university?

Mr. Graves. Before the technical students in the forestry school.

Mr. Booner. Were these students studying forestry?

Mr. Grives. Yes; it was a technical forest school.

Mr. Moss. Who is Mr. Thomas R. Shipp?

Mr. Grives. Mr. Thomas R. Shipp was employed hy the Forest Service. Ife is no longer comnected with the service. What his duties were I do not know. 


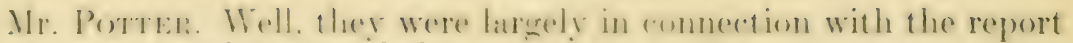
of the conservation commission.

Mr. Moss. That brings up a whole line of questions. What connecolion hat your depatment with the maintaining of a bureau of publieity he which rou male clippines from the papers and grive out statements, and so forth?

Mr. Cirates. We are semling out maa-iomally news items remarding the work of the Forest service, just as is clone in a number of the

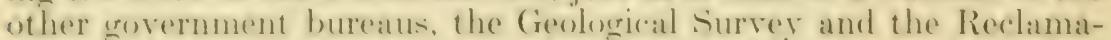
tion Serviee. When work is of interest to the publice, which does not anstitute a latrese enough work for publication in a circular or in a resular bulletin. items are sent out to interested individuals and the press. The process is to semel those orer to the department, and they are pasiofl on by the secretary or his immediate asisistants, and they are sent out oflicially.

Mr. Moss. What kind of newspaper elippings do gou take and preserve in your department?

Mr. Creares. Clipping- regarding the work of the Forest Gerviee.

Mr. Moss. The item here is, "Thomats R. Shipp, tripto New York on the husinese of the Fonest service relating to the eollection of newspaper relippines s.20." What purpese would gou have in sending a man to New York to collect newspaper clippings?

Mr. Graves. I do not know, unless it was to arrange with some soncern regareliug exactly what we required in the Forest service in the way of clippings.

Mr. Potter. The only occasion would be to arrange with a newspuper elipping agener for lumbhing the Forest Service with such clipping as it neceled. feoling that we condel grive them a better idea of just what we wanted hy going there and talking it orer than by writing letters.

Mr. Booner. Let me suggest to you that Mr. Vertrees, with his usual fairness, has that amount wrong. Instead of $\$ 20$ it is $\$ 15$ in the book of expenses.

Mr. Moss. 'This matter was referred to in Mr. 'Tawney's address on the flowe of the Inome, in recard to newspaper elippings, and that is the reason I wanted to hring this out. Are rou making and preserving new-palper clipponge relat ing to the individual work or the (a)lective work: that is. work of individual members of your department, or relating in a general way to the results from your whole department?

Ir: (iRsves. The clippings relate to the work of the Forest service, and where an indivilual has done some work clippings will come in; for instance, frequently there were reports of my western trip coming to the Forest Service.

Mr. Potter. 'The idea is to cover the general field of the Forest Service work and of forestry, for the information of the service.

Mr. Mass. Mas your department placed orders with these agencies to make a husinesis of collereting elippings and semeling them to the department"

Mr. Graves. We have an arrangement with a clipping bureau.

Mr. Potter. This is clone under the approval of a departmental committee on press clippings.

Mr. Jappove. At the time Mr. Moss speaks of we had a special arrangement with one of the presselippoine hureaus independent of the department contract. 
Mr. Booher. Do all of these government departments have a press-clipping bureau?

Mr. Potter. I think they do.

Mr. Graves. They receive clippings.

Mr. Zappone. They are not called press-clipping bureaus; the department merely receives clippings which in some way criticise its work. It is seldom that the clippings sent in repeat information that the department has published. Each press bureau writes to the department and asks as to the class of clippings desired and is instructed as to what to send; and of what is sent, as a rule, we reject probably one-third, under an arrangement we have with the clippings bureau as to the class of clippings desired.

Mr. Booher. Let me ask you right there. This press-clipping arrangement in the Bureau of Forestry is no different than the pressclipping arrangement in the other bureaus of the departments of the Government?

Mr. Graves. No; I think it is just the same in our department as it is in the other departments.

Mr. Potter. It is on the same general plan.

Mr. Moss. Who is Mr. A. C. Shaw?

Mr. Graves. He was one of the law officers of the service: he is no longer connected with the service.

Mr. Moss. Where was his office?

Mr. Graves. In Washington.

Mr. Moss. The item referred to is "A. C. Shaw, Washington to Toronto, Canada, to deliver an address on forest taxation at the International Tax Conference, $\$ 53.80$."

Mr. Graves. The question of forest taxation is an exceedingly important question in the whole question of forestry: that is, as to private lands, and the Government has been studying the question of forest taxation with reference to its application to the introduction of forestry on private lands. And this was a meeting of the tax commission, was it?

Mr. Moss. An international tax conference.

Mr. Graves. An international tax conference, and Mrr. Shaw had charge of the tax study in the Forest Service, and he went up to that conference and undoubtedly gave a talk and met the men there to exchange ideas regarding this important subject.

Mr. Mloss. It speaks of this being international. Did the United States Government get an invitation to attend it as a member of the international conference?

Mr. Graves. I could not tell about that, sir.

Mr. Potter. I think they did, sir.

Mr. Moss. But you can not tell positively whether that is true or not?

Mr. Potter. No, sir.

Mr. Moss. Can either one of you tell under what conditions Mr. Shaw went to Toronto, how the invitation reached him, or what invitation reached him?

Mr. Graves. Well, it was probably an invitation to the Forest Service to delegate some one for that conference.

Mr. Moss. But that is a presumption on your part?

Mr. Graves. Yes, sir. 


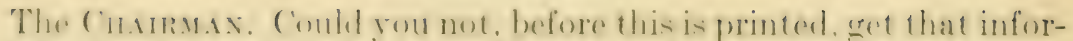
mation and insert it in the record?

Mr. Graves. Yes, sir.

The facts were as follows: The Toronto International Conference was held under the auspices of the National Tax Association, an organization of publiciste. comomists. and others interested in the problems of exputable and scientilic taxation of property. ()ne of

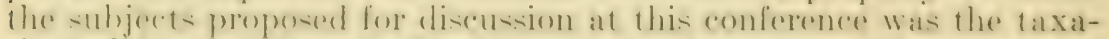
tion of forested lands. The Forest Service was requested by the association to send a representative to take part in the discussion, and if pusithe to semel Mr. Shaw, who had previously been in correspondenere with the president of the assoriation and was qualified to speak with special linowledge of the legal questions involved. Jir.

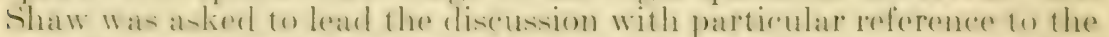
constitutional limitations in the several states which might interfere with the adoption of better methods of taxing forested lands.

Mr. Moss. In regard to these diflerent items which I have read do you consider that any of those exceeded the authority of the department under the lat or good poliey and are justly subjeet to criticism as being unwarranted by law?

Mr. Graves. I can not see how they were not justified by law. I think, as I stated in my testimony, that the sending of a man to adclees an audience componed of members of a Y. M. C. A-although I do not know the circumstances-might have been of questionable wistom: otherwise I can not see that there should be any atricism as to any other case.

The Chammax. There was no violation of the law?

Mr. Graves. No, sir; I do not see any violation of the law in that ("isce.

Ir. Booner. Vo violation of the law and no violation of any regrulation and proper julgment about the distribution of information that the department has?

Mr. Graves. No, sir.

lir. Booner. And there was no bad faith connected with it in any way?

Mr. Graves. No, sir.

Mr. Booner. There might be bad faith, and yet no violation of the law. Do you see anything of that sort connected with it?

Mr. Graves. No, sir.

The Chamsix. In your judgment were all of these items to which Mr. Mor-har-directed bour attention justified and for the benefit of the service, with the possible exception of the one you spoke of?

Mr. Grares. That might hatre been emtirely justifeel.

The Cinirmax. I say with the exception of that one?

Mr. Graves. In looking over the travel book, as I have at various times, it seems to me that the expenditures are justified.

Mr. Booner. These Y. M. C. A.'s are usually composed of young men who are very anxious to gather information on certain subjects, are they not, and are lectured to by various prominent people?

Mr. Graves. Yes, sir.

Mr. Booner. Would your idea be now, without having an oppor-

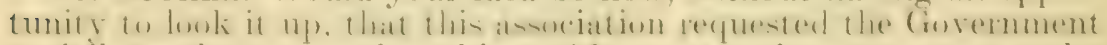
to deliver a lecture on the subject of forestry to these young men who composed the association? 
Mr. Graves. They undoubtedly requested us to deliver that lecture on forestry.

Mr. Boorer. And these associations are usually supported by the people and by public subscriptions, are they not?

Mr. Graves. Yes, sir.

Mr. Moss. There is just one other matter that I wish to refer to. Judge Booher has referred to it rery fully. It is in rearal to the question of cooperatine with certain people. I see you have been cooperating with the Tennessee ('oal and Iron (ompany. I think rou will find it on page 100, "John M. Nelson, jr., Itashington to Birmingham. Ala., and return, July 21 to August S, 190S, to supervise plans for wood-preserving policy for Temmesses coal and Iron ('ompany, \$110.01." Tow, then, will you please explain under what arrangement the forestry department sent that person at public ('xpense to supervise plans for wood-preserving policies for the Tenmesese (oal and Irom Company, which I understand is a very large and wealthy corporation?

Mr. Graves. The policy has been to cooperate with concerns of that sort when it is justified from the results anticipated. Now, the Forest Service has been working for that concern in connection with the examination of woodlands where we wanted to wet information about that particular part of the comery and about the forests, but in pracetically all of that work, as I understand it, the expenses were borne by the company. Whether this was the initial investigation, the initial trip), or not. I do not know. Sometimes that was done; it was to talk over the whole question of the introduction of forest work which would lead to the introduction of forestry in a region which was not interested in it at all.

Mir. Moss. Another item appears here, "Mr. P. Piper, forest assistant, Washington to Birmingham, Ala, and return. Febluarr 12 to April 19, 1909, study of forest comelitions in northern Dlabama in cooperation with the "Temnessee Coal, Iron and Railroal ('ompany." I see several such items throughout these pases, and in cach case the department has paid the expenses.

Ir. Graves. Well, that was presumably in connection with work where we were deriving definite bemefits from the examination and knowedge of the timber and a knowledge of the growth of the rees, all of which was a contribution to our knowledge of the forests.

Mr. Moss. Then this not a fair statement of the matter

Mr. Grates. I do not think that is clear, as to just what that means.

Mr. Moss. It looks to me as thouere it meant the furnishine of an expert for the benefit of the company, if this is a fair statement of it.

Mr. Graves. I know there was a good deal of work done down there, where there never had been any interest in forestry at all, and the purpose was to get forestry started in that part of Alabama. As to that particular case I can not answer direstly; I would have to look that up). We are very careful not to have a public expenditure in connection with cooperative work except where there is a direct benefit from the standpoint of gettinge information of seientifie value for our work.

Mr. Moss. I believe I will ask you to place in the record complete data as to Mr. Selson's trip and the particular work that he dirl in regard to supervising plans in that particular ('ase: also plate in the record under what authorization or request the work was done. 
I will also ask you to place a detailed report in the record as to all of these matters, as there are several items rumning through here.

Mr. Booner. On page 103 I find this item, "Fred G. Plummer, geographer, instructions and help to supervisors in preparation of data for the Forest Atlas, \$366.46." What kind of a publication is the Forest Atlas?

Mr. Potter. The Forest Atlas is a complete series of maps of the mational forent- - howing the trpe of country, what portion is cosered with merchantable timber, what portion is covered with woodland, what portion has been cut over, what portion has been burned, what pertion is erazing land, and in the timber land. indirating the different stands of timber, one zone being timber that rums from five to ten thousand feet to the acre, and another from ten thousand to twenty thousand feet to the acre, and so on; also showing the status of the latul ats to the exare location of the lands that are under private ownership.

Mr. Booner. In other words, it is aimed to be a geography of the forest reservations and forest lands of the country?

Mr. Potter. I'es, sir.

Mr. Boner. What is to be tone with that work when completed?

Mr. Potter. Parts of it are placed in the hands of the supervisors, the maps relating to their own forests.

Mr. Booller. Is it for distribution?

Mr. Potter. No, sir: for official use.

Mr. Booner. It is for official use?

Mr. Potter. Yes, sir.

Mr. Booner. Is this all the expense attached to it, $\$ 366.46$ ?

Mr. Potter. No, sir; that was the expense incurred in making a trip for the purpose of gathering information.

Mr. Booner. Have you any of those geographies completed and in use now?

Mr. Potter. Yes, sir; we have them completed for over 100 of the national forests. But the atlas as a whole will never be completed.

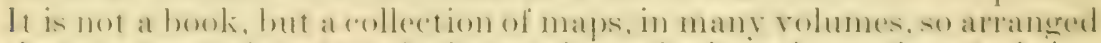

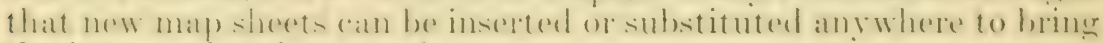
the information down to date.

Mr. Bombr. Here is one of the items about which Mr. Vertrees complained, "Bristow Adams, Washington to Chicagro, to meet members of women's clubs with regard to extension of forest education, \$77.31." Were those clubs organized for the purpose of teaching forestry ?

Mr. Potter. Forestry is one of the subjects that these clubs study. They have regular courses, with leaders, on all sorts of subjects.

Mr. Graves. They were general women's elubs.

Mr. Boomer. II is the department invited to send a lecturer to those clubs for that purpose?

Mr. Graves. Yes, sir.

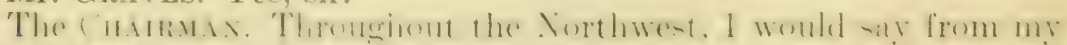
own knowledge, the women's chubs have given a great deal of attention

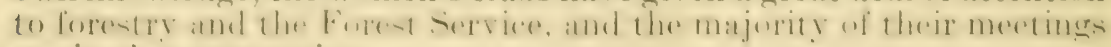
are in that comnection.

Mr. Booner. Now, an to the expenses of Mr. G. S. Arnold; ats I understand it he is a law oflicer of the department?

Mr. Potren. Yes, sir: he was. 
Mr. Booher. And his business in this connection was the inspection of these different offices?

Mr. Potter. Yes, sir; that was the principal object of his visit, to confer with the local law officers.

Mr. Booher. And that was regarded as a necessary expense of the department, and it ought to have been expended?

Mr. Potter. Yes, sir.

Mr. Booher. And that would have been expended in that way if you had had a definite appropriation for that purpose?

Mr. Potter. Oh, yes, sir.

Mr. BooHer. I think you fully explained the item with regard to the man in charge of the government exhibit at Seattle?

Mr. Potter. Yes, sir.

$\mathrm{Mr}$. Booher. And during the time he was there he gave these educational talks?

Mr. Potter. Yes, sir.

Mr. BooHer. And the explanation in the book of expenses simply gives a general idea of what the duties were, and does not pretend to state all of his duties?

Mr. Potter. That is right.

Mr. Booher. Now, as to the Tennessee Coal and Iron Company. I want to say that I agree with Mr. Moss; I do not think the Government ought to do very much for the Tennessee Coal and Iron Company; I think they are abundantly able to pay if they want any information at all.

Mr. Moss. I thought that item ought to be fully explained.

Mr. Graves. Mr. Zappone has just called my attention to the fact that that money was paid by the Tennessee Coal and Iron Company. They put up $\$ 5,200$ during that year. These amounts were paid out by the Forest Service and went into these expenses, but were charged up against that $\$ 5,200$.

Mr. Moss. Well, that explains the whole proposition.

Mr. Graves. On page 138 of Document No. 421 is an item, "Tennessee Coal and Iron Company, $\$ 5,200$." That amount was paid in by that company. In all of these cooperative examinations the private owner makes a deposit with the department to cover what we expect the probable expense will be, or what we estimate the expense to be, and then if there is any balance after the expense has been paid it is refunded to them, and if the amount is insufficient an additional deposit is called for.

Mr. Moss. I am very glad to know that; that is what we wanted to get at.

(Thereupon the committee adjourned.)

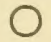





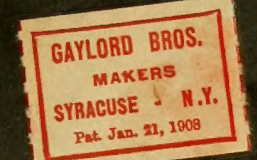


LIBRARY OF CONGRESS 